\title{
Ankara'da faaliyet gösteren bir tıpta uzmanlık dershanesine devam edenlerin bazı beslenme alışkanlıkları ve beslenme durumlarından memnuniyetlerinin belirlenmesi
}

\author{
Meal preferences and satisfaction of nutrional status of medical students and \\ senior doctors attending to a private medical speciality examination course.
}

M. Tolgahan Örmeci, Eda Odman, Ahmet Olgun, Hüseyin Adil Öner, Cavit Işık Yavuz*, Çağatay Güler

Hacettepe Üniversitesi Tıp Fakültesi (Dr. M. T. Örmeci, Dr. E. Odman, Dr. A. Olgun, Dr. H. A. Öner), Hacettepe Üniversitesi Tıp Fakültesi Halk Sağlığı Anabilim Dalı (Doç. Dr. C. I. Yavuz, Prof. Dr. Ç. Güler) Hacettepe Üniversitesi Tıp Fakültesi TR-06100 Ankara

\begin{abstract}
Özet
Amaç. Bir Tıpta Uzmanlık Sınavı dershanesinde tıp öğrenci ve mezunlarının beslenme ve yemek tercihleri ile beslenme durumlarından memnuniyetlerini belirlemek. Yöntem. Tanımlayıc özellikteki çalışmada veriler TUS dershanesine devam eden 231 tıp öğrencisi ve mezunundan anket yardımıyla toplanmıştır. Bulgular. Katılımcıların \%60,6'sı kadın ve \%77,1'i 25 yaş altındadır (Ortalama 23,5 $\pm 2,0$ yıl). Tıp öğrencileri \%66,2'sini oluşturmuştur. Katılımcıların \%72,7'si DSÖ kriterlerine göre normal ağırlıktadır. Öğle yemeği barındıkları yer dışında (aile yanında, arkadaşlarla ya da tek başına evde, öğrenci yurdunda) en sık yenilen öğündür. Katılımcıların üçte biri beslenme durumundan yarısı da fizik aktivitelerinden memnun değildir. Beslenme memnuniyetsizliği ile ilişkili faktörler yaş, mezun olup olmama ve vücut kitle indeksi (VKI) olarak tespit edilmiştir. Sonuçlar. Sağlıklı davranışlar günümüzün sağlık anlayışında anahtar bir rol oynamaktadır. Tıp öğrencileri ve hekimler sağlık eğitimi programlarının önemli gruplarındandır ve bu nedenle bilgi ve tutumları toplum için önem kazanmaktadır. Bu grubun sağlık risklerine dair daha ayrıntılı çalışmalar yapılmalıdır. Tıpta uzmanlık sınavı süreci bu grubun beslenmelerini etkilemektedir.
\end{abstract}

Anahtar sözcükler: Beslenme durumu, tıp öğrencileri, hekimler

\begin{abstract}
Aim. To assess the nutrional and meal preferences and satisfaction of a group of medical students and senior doctors at a private medical specialization examination course (MSE). Methods. In this descriptive study, data were collected with a questionare from 231 medical students and senior doctors who attended the medical speciality examination course. Results. $60.6 \%$ of participants were female and 77.1\% of them were under 25 years old (Mean 23,5 2,0 year). Medical students were $66.2 \%$ of all participants. $72.7 \%$ of medical students and senior doctors in the study, had normal weigth for WHO criteria. Lunch is the common meal that eaten outside of their accomodation (with family, with friend or alone at home and student hostels). They preferred fast food meals. One third of participants were unsatisfied with their nutrional status and half of them were unsatisfied their pyscial activity. Related factors with unsatisfactory of nutrional status were identified age, being senior doctors or not and body mass index (BMI). Conclusions. Healthy behaviour plays a key role in today's health concept. Doctors and medical students are mainly part of groups of health education programs. For this reason their knowlegde and attitudes are important for society. Detailed studies and interventions are recommended their behaviours about health risks. Medical speciality examination is a factor on chancing their nutrional status.
\end{abstract}

Keywords: Nutritional status, students, medical, physicians 


\section{*İletişim adresi:}

Dr. Cavit Işık Yavuz, Halk Sağlığı Anabilim Dalı, Hacettepe Üniversitesi Tıp Fakültesi TR-06100 Ankara. E-posta: cavityavuz@gmail.com

\section{Giriş}

Bugün için sağlık, çeşitli yönlerden bir iyilik hali olduğu kadar bu iyilik halini koruma ve geliştirmeyi de içeren bir kavram olarak gelişmektedir. İyilik halini oluşturmak, sürdürmek ve geliştirmek birçok faktörün yanı sıra yeterli ve dengeli beslenme ile mümkündür [1]. Beslenme çok yönlü ve boyutlu bir konudur ve yaşam tarzının ve davranışların değişimi, beslenme ile ilgili algı ve alışkanlıkları da değiştirmektedir. Gerek bireysel, gerek toplumsal gerekse de küresel düzeyde etkili faktörler bu değişimin temelinde yatmakta ve bu durum beslenme sorunlarını halk sağlığı açısından ön plana getirmektedir, bu açıdan sağlıklı olmak hali için yeterli ve dengeli beslenme giderek daha fazla önem kazanmaktadır [2, 3].

Beslenme alışkanlıklarındaki değişikliklerin farkında olmak ve bunların ekonomik, sosyodemografik faktörler ve sağlik ile olan ilişkilerini saptamak, beslenme alışkanlıklarının nedenlerini ve sonuçlarını anlamaya önemli ölçüde 1şık tutmaktadır. Neden ve sonuçlara ilişkin değerlendirmeler, insanların daha sağlıklı beslenmeleri için gereken değişikliklerin yapılabilmesi ve geliştirilebilmesi konusunda yardımcı olacaktır [4]. Beslenme sorunlarının gerek hazırlık ve planlama gerekse de yürütülmesi ve değerlendirilmesi süreçlerinde sağlık çalışanları kilit rollere sahiptir. Bu kilit rol sadece mesleki rol ve işlevlerinden değil, sağlık meslek grubu olarak "rol modeli olma" fonksiyonlarından da gelmektedir.

Günümüz insanının beslenme alışkanlıkları teknolojinin gelişmesi, kentleşme, yoğun iş temposu, daha sık ve uzun süreli seyahat etme, yalnız yaşama gibi etkenler nedeniyle farklılaşmakta, beslenmeye daha az zaman ayrilarak geleneksel beslenme alışkanlıklarından uzaklaşma yaşanmaktadır. Yeni tip bir beslenme tarzı olarak "ayaküstü beslenme" ya da "hızlı hazır yemek sistemi" olarak belirtilen beslenme biçimlerinin yaygınlaştığı vurgulanmaktadır. Bu tarz beslenme sistemi, özellikle "günü evinden uzak geçiren insanların" tercih etiği bir sistem olarak öne çıkmaktadır [5].

Kuşkusuz ister ev dışında ister ev içinde tüketilsin, yenilen öğünlerin içeriği yeterli ve dengeli beslenme açısından önem kazanmaktadır. Buna karşılık "ayaküstü/hızlı hazır yemek sistemi" ile tüketilen besinler beslenme açısından değerlendirildiğinde bazı yönlerden sorunlu bir içerikte olduğu görülmektedir. Bu sorunlar arasında \%40-60'1 yağlardan gelen yüksek düzeyde enerji içermeleri, vitamin içeriklerinin değişken oluşu, posa açısından fakir oluşları sayılabilir [5] .

Son yıllarda ev dışında yenilen "ayaküstü” öğünlerin içeriğinin daha sağlıklı hale gelmesi yönünde bir eğilim ortaya çıkmaya başlamıştır. Bu amaçla yiyecek ve içecek türlerinin biçim ve içerikleri ve değişime uğramaktadır [6].

Beslenme biçimi ve alışkanlıkları bireyin bulunduğu yaş grubuna göre özellikler gösterir. Somatik olarak 12-21 yaş arası olaral kabul edilen ergenlik döneminde, Dünya Sağlık Örgütü (DSÖ) tarafından "gençlik dönemi" içerisinde sınıflanan üniversite öğrencilerini kapsayan dönem ile yetişkin döneminin erken evreleri hayata atılma, dış etkilere açık hale gelme, giderek kendi özgür seçimlerini yapma açısından özellik gösteren dönemlerdir. $\mathrm{Bu}$ dönemdeki beslenme alışkanlıkları erişkin döneme taşınabilmekte ve yerleşebilmektedir $[7,8]$. Bu geçiş döneminde kazanılacak doğru beslenme alışkanlıkları yaşamın geri kalan döneminde de sürdürülmesi açısından önemli müdahale alanlarındandır.

Ülkemizde gençlerin beslenme alışkanlıkları ile ilgili araştırmalarda bu dönemde beslenme ile ilgili çok ciddi sorunların yaşandığı görülmektedir. Öğrencilerin genellikle ögünlere dikkat etmedikleri, öğün atladıkları, yurtlarda kalan öğrencilerin beslenme alışkanlıklarının istenildiği düzeyde olmadığı saptanmıştır [9]. 
Günümüzde gençlerin beslenme alışkanlıkları sağlıklı beslenme kurallarının dışına çıkarak özellikle ayaküstü beslenme tarzının öne çıktığı farklı bir boyut kazanmıştır. Gençler onlara yönelik gelişen ve cazip gelen yă̆ ve karbonhidrat içeriği zengin yiyecekleri tüketerek ideal kilolarının üzerine çıkmakta, bu da onları çeşitli biçimlerde rahatsız etmektedir. Sağlıklı beslenme kurallarını öğrenmek ve uygulamak gençler için önemi gittikçe artan bir konu haline gelmiştir [10]. Üniversite dönemi ve genç erişkinlik dönemindeki beslenme alışkanlıkları arasında dışarıda yenilen ögünlerin sıklığını ve içeriğini belirlemek sağlıklı yaşam davranışları açısından geliştirilecek programlara önemli veriler ve katkılar sağlayacaktır.

Bu çalışma, Ankara'da faaliyet gösteren bir Tıpta Uzmanlık Sınavı (TUS) dershanesine devam eden tıp fakültesi öğrencileri ve mezunlarının kaldıkları yer (ev, yurt vb) dışında tükettikleri öğün sıklığını, dershanede bulundukları süre içerisinde öğün tercihlerini, beslenme durumlarından memnuniyetlerini ve ilişkili olabilecek faktörleri belirlemeyi amaçlamaktadır.

\section{Gereç ve yöntem}

Araştırma, tıp fakültesi öğrencilerini ve mezunlarını TUS'a hazırlayan ve Ankara'da faaliyet gösteren özel bir TUS dershanesinde gerçekleştirilmiştir. Tanımlayıcı tipte olan araştırmada dershaneye devam eden 231 tıp fakültesi öğrencisi ve mezunu katılmıştır. Araştırmada 9'u açık uçlu, 21'i çoktan seçmeli olan toplam 30 sorudan oluşan bir anket formu kullanılmıştır. Anket formunda yer alan soruların 11'i katılımcıların sosyodemografik özellikleri, 7'si dershaneye devam süreleri ve dershanedeyken dışarıda yenilen öğünlerin sıklığ 1 ve bu öğünlere ayrilan zaman ve para, 12'si de genel beslenme alışkanlıklarını, dershanedeyken dışarıda yenilen ögünlerde tercih edilen yiyecek ve içecekleri, genel olarak beslenme memnuniyet durumunu belirlemeye yöneliktir. Anket ön denemesi yapıldıktan ve gerekli düzenlemeler gerçekleştirildikten sonra veriler 1-7 Aralık 2012 tarihleri arasında gözlem altında toplanmıştır.

Araştırma katılımcılarından isim alınmamış, araştırma hakkında bilgi verilmiş ve katılıma davet edilmiş, kabul edenlere anket formu uygulanmıştır. Araştırma ile ilgili olarak ilgili Dershane Müdürlüğü'nden yazılı izin, H.Ü.T.F. Girişimsel Olmayan Araştırmalar Etik Kurul'undan etik kurul onayı alınmıştır.

Araştırmada elde edilen veriler, oluşturulan bir veri tabanı ile SPSS 15.0 istatistik paket programı ile analiz edilmiştir. Analizlerde Ki Kare ve Pearson korelasyon testleri kullanılmış, istatistik değerlendirmelerinde, olasılığ $\mathrm{p}<0.05$ değerler istatistiksel olarak anlamlı kabul edilmiştir.

\section{Bulgular}

Araştırmaya katılan tıp fakültesi öğrencisi ve mezunlarının \%39,4'ü erkek, \%60,6's1 kadındır. Çalışma grubunun \%77,1'i 25 yaş altında (Yaş ortalaması 23,5 2,0 yıl), $\% 22,9$ 'u 25 ve üstü yaş grubundadır, \%66,2'si tıp fakültesi öğrencisi, \%90,9'u bekardır. Katılımcıların \%7,4'ü araştırma sırasında çalıştığını, \%78,9'u aylık gelirinin (Maaş, harçlık, burs vb toplamı) 1000 TL ve altı olduğunu, \%32,9'u ailelerinin yanında yaşadıklarını bildirmiştir. Anne ve baba eğitim durumlarına ilişkin olarak \%71,2'sinin anne eğitiminin, \%80,9'unun baba eğitiminin lise ve üzeri olduğu saptanmıștır. TUS dershanesine devam eden katılımcıların \%72,7'si DSÖ kriterlerine göre normal kiloludur. Araştırma katılımcılarının bazı sosyodemografik özellikleri ve Vücut Kitle İndeksi(VKI) değerlendirmeleri Tablo 1'de verilmiştir.

Katılımcıların \%76,9'u düzenli fizik aktivite (haftada en az beş, günde en az bir saat süreyle yürüme, koşma, spor vb aktiviteler) yapmamaktadır. Araştırma katılımcılarının son bir hafta içerisinde kaldıkları yer dışında yedikleri yemek sıklığı incelendiğinde (Tablo 2) öğle yemeğinin en sık dışarıda yenen öğün olduğu izlenmektedir. Son bir haftada katılımcıların \%20,5'i bir ya da iki kez, \%69,9'u ise üç ve daha fazla kaldıkları yer dışında yemek yemiştir. İkinci sırada akşam yemeği gelmektedir. Son bir hafta içinde kalınan yer dışında yenen ögün toplamı ortalaması 9,0 5,4 olarak tespit edilmiştir. 
Tablo 1. Araştırma katılımcılarının bazı sosyodemografik özellikleri ve VKI değerlendirmeleri (ANKARA, 2012).

\begin{tabular}{|c|c|c|}
\hline Özellik & Sayı & $\%$ \\
\hline \multicolumn{3}{|l|}{ Cinsiyet $(n=231)$} \\
\hline Erkek & 91 & 39,4 \\
\hline Kadin & 140 & 60,6 \\
\hline \multicolumn{3}{|l|}{ Yaș Grubu (n=231) } \\
\hline$<25$ yaş & 178 & 77,1 \\
\hline$\geq 25$ yaş & 53 & 22,9 \\
\hline \multicolumn{3}{|l|}{ Öğrenim Durumu (n=231) } \\
\hline Tıp Fakül Donem 4 & 4 & 1,7 \\
\hline Tip Fakültesi Donem 5 & 149 & 64,5 \\
\hline Tıp Fakültesi Donem 6 & 25 & 25 \\
\hline Tip Fakültesi Mezunu & 53 & 22,9 \\
\hline \multicolumn{3}{|l|}{ Medeni Durum (n=231) } \\
\hline Evli & 21 & 9,1 \\
\hline Bekâr & 210 & 90,9 \\
\hline \multicolumn{3}{|c|}{ Katılımcının çalıșma durumu $(n=231)$} \\
\hline Çalışıyor & 17 & 7,4 \\
\hline Çalışmiyor & 214 & 92,6 \\
\hline \multicolumn{3}{|c|}{ Katılımcının toplam aylık geliri $(n=199)$} \\
\hline 1000 TL ve altı & 157 & 78,9 \\
\hline 1001-2000 TL aras1 & 20 & 10,1 \\
\hline 2001 TL ve üstü & 22 & 11,1 \\
\hline \multicolumn{3}{|l|}{ Yaşam yeri $(n=231)$} \\
\hline Aile yanı & 76 & 32,9 \\
\hline Arkadaşlarla evde & 64 & 27,7 \\
\hline Yurtta & 60 & 26,0 \\
\hline Evde yalnız & 27 & 11,7 \\
\hline Akraba yanı & 3 & 1,3 \\
\hline Diğer & 1 & 0,4 \\
\hline Vücut Kitle İndeksi(n=227) & Say1 & $\%$ \\
\hline Zayıf & 14 & 6,2 \\
\hline Normal kilolu & 165 & 72,7 \\
\hline Fazla kilolu & 40 & 17,6 \\
\hline Şişman & 8 & 3,5 \\
\hline
\end{tabular}

Tablo 2. Dershaneye devam eden katılımcıların son bir haftada kaldıkları yer dışında yeme durumları $(\%)$.

\begin{tabular}{lccc}
\hline \multicolumn{1}{c}{ Öğün } & $\begin{array}{c}\text { Hiç } \\
\text { \% }\end{array}$ & $\begin{array}{c}\mathbf{1 - 2} \text { kez } \\
\text { \% }\end{array}$ & $\begin{array}{c}\text { 3'ten fazla } \\
\text { \% }\end{array}$ \\
\hline Kahvaltı $(\mathrm{n}=229)$ & 41,5 & 23,1 & 35,4 \\
Öğle (n=229) & 9,6 & 20,5 & 69,9 \\
Akşam (n=227) & 22,5 & 31,7 & 45,8 \\
\hline *Tabloda sunulan yüzdeler satır yüzdesidir. \\
\hline
\end{tabular}


Katılımcıların dershaneye devamları sırasında kaldıkları yer dışındaki ögünlerine dair bazı özellikler Tablo 3 'te sunulmuştur.

Tablo 3. Araştırma katılımcılarının dershaneye devamları sırasında kaldıkları yer dışında tükettikleri öğün sıklığı ve bu öğüne harcanan para miktarı.

\begin{tabular}{lll}
\hline Dershaneye gidilen günlerde dışarıda yemek yeme $(\mathbf{n = 2 3 1})$ & Sayı & \% \\
\hline Her zaman & 167 & 72,3 \\
Sıklıkla & 42 & 18,2 \\
Nadiren & 16 & 6,9 \\
Hiçbir zaman & 6 & 2,6 \\
\hline Dershaneye gidilen günlerde günlük yemeğe ayrılan para(n=228)* & & \\
\hline 10 TL ve altı & 119 & 52,2 \\
11-20 TL arası & 97 & 42,5 \\
21 TL ve üstü & 12 & 5,3 \\
\hline *Ortalama $\pm \mathrm{SS}=13,84 \pm 7,84$ TL, ortanca 10 TL. & & \\
\hline
\end{tabular}

Araştırma katılımcıları dershaneye gittikleri günlerde dışarıdan en sık tükettikleri (Sıklıkla ve her zaman) yiyecek türleri arasında ilk üç sırayı ekmek arası ürünler $(\% 59,0)$, lahmacun/pide/pizza(\%39,0) ve hamburger ve patates kızartmas1 $(\% 38,0)$ almaktadır (Tablo 4).

Tablo 4. Dershaneye devam eden katılımcıların dışarıdan karşıladıkları öğünlerde tercihleri ve sıklığı (\%) (ANKARA,2012).

\begin{tabular}{|c|c|c|c|c|}
\hline Öğün tercihi & $\begin{array}{c}\text { Hiçbir zaman } \\
\%\end{array}$ & $\begin{array}{c}\text { Nadiren } \\
\%\end{array}$ & $\begin{array}{c}\text { Siklıkla } \\
\%\end{array}$ & $\begin{array}{c}\text { Her zaman } \\
\%\end{array}$ \\
\hline Ekmek arası ( Köfte, döner, tavuk vb) $(\mathrm{n}=212)$ & 8,5 & 32,5 & 48,6 & 10,4 \\
\hline Lahmacun, pide, pizza vb. $(n=197)$ & 13,2 & 47,7 & 36,0 & 3,0 \\
\hline Hamburger, patates k1zartması $(n=192)$ & 29,7 & 32,3 & 34,4 & 3,6 \\
\hline Kebap $(n=185)$ & 29,7 & 44,3 & 23,2 & 2,7 \\
\hline Çorba $(n=185)$ & 44,9 & 29,2 & 22,7 & 3,2 \\
\hline Balık $(n=182)$ & 45,6 & 43,4 & 9,9 & 1,1 \\
\hline Meyve (n=185) & 47,0 & 29,7 & 16,2 & 7,0 \\
\hline Sebze yemekleri $(n=181)$ & 55,2 & 27,6 & 16,0 & 1,1 \\
\hline Kuru baklagil yemekleri $(\mathrm{n}=176)$ & 64,2 & 23,9 & 11,4 & 0,6 \\
\hline Makarna $(\mathrm{n}=175)$ & 57,7 & 33,7 & 7,4 & 1,1 \\
\hline
\end{tabular}

Araştırma katılımcılarının dershaneye devamları sırasında dışarıda yedikleri yiyecekleri seçimlerinde belirleyici 3 faktörü belirtmelerine dair soruya verdikleri yanıtlar incelendiğinde bu soruya yanıt veren katılimcilardan \%32,3'ünün "çabuk yenme, lezzet ve temizlik" özelliklerini bir arada değerlendirdikleri dikkati çekmektedir(Tablo 5).

Tablo 5. Dershaneye devam eden katılımcıların dershaneye gittikleri günlerde dışarıda yemek yedikleri sırada yemek seçimlerini belirleyen en önemli 3 faktör (ANKARA,2012).

\begin{tabular}{lll}
\hline Seçim faktörü & Sayı & \% \\
\hline Yemeklerin çabuk yenmesi, lezzetli olması, temiz olması & 43 & 32,3 \\
Yemeklerin çabuk yenmesi, lezzetli olmas1, doyurucu olmas1 & 27 & 20,3 \\
Yemeklerin lezzetli olmas1, temiz olması, doyurucu olmas1 & 25 & 18,8 \\
Yemeklerin çabuk yenmesi, temiz olması, doyurucu olması & 19 & 14,3 \\
Yemeklerin çabuk yenmesi & 19 & 14,3 \\
\hline Toplam & $\mathbf{1 3 3}$ & $\mathbf{1 0 0 , 0}$ \\
\hline
\end{tabular}

Katılımcıların \%57,9'u dershaneye gittikleri günlerde yedikleri yemekleri sağlıklı bulmadığını, \%22,8'i bu konuda fikri olmadığını belirtmişlerdir. Katılımcıların \%19,3'ü yediklerini sağlıklı bulmaktadır. Dışarıda yenen yemeklerle ilgili ailelerinin düşünceleri ile ilgili olarak ise katılımcıların\%32,5' $\mathrm{inin}(\mathrm{n}=231)$ ailelerinin dışarıda yedikleri yemeği bildikleri ve uygun bulmadıkları, \% 31,6'sının ne yediklerini bilmedikleri, \% 19,9'unun ailelerinin dışarıda yediklerini bildikleri ve uygun buldukları, \%16,0'sının ise ailelerinin dışarıda yedikleri ile ilgilenmedikleri belirlenmiştir. 
Genel olarak katılımcıların beslenme durumlarından, fizik aktivitelerinden ve vücut ağırlıklarından memnuniyet düzeylerini değerlendirmeleri istendiğinde katılımcıların beslenme durumlarıla ilgili olarak sırasıyla "fena değil"'(\%34,2), "memnunum" (\%27,3), "memnun değilim"(\%26,8), "hiç memnun değilim"(\%6,1) ve "çok memnunum"(\%5,6) yanıtlarını tercih ettikleri belirlenmiştir. Fizik aktivitelerinden hiç memnun olmayanlar ve memnun olmayanlar sırasıyla \%22,9 ve \%33,3'tür, vücut ağırlığından memnuniyetsizlikte ise bu yüzdeler sırasıyla \%14,8 ve \%19,1 olarak belirlenmiştir (Tablo 6).

Tablo 6. Dershaneye devam eden katılımcıların beslenme, fizik aktivite ve vücut ağırlıklarından memnuniyetleri $(\mathbf{n}=\mathbf{2 3 1})$.

\begin{tabular}{lll}
\hline Beslenme durumundan memnuniyet $(\mathbf{n = 2 3 1})$ & Sayı & \% \\
\hline Hiç memnun değilim & 14 & 6,1 \\
Memnun değilim & 62 & 26,8 \\
Fena değil & 79 & 34,2 \\
Memnunum & 63 & 27,3 \\
Çok memnunum & 13 & 5,6 \\
\hline Fizik aktiviteden memnuniyet(n=231) & & \\
\hline Hiç memnun değilim & 53 & 22,9 \\
Memnun değilim & 77 & 33,3 \\
Fena değil & 58 & 25,1 \\
Memnunum & 33 & 14,3 \\
Çok memnunum & 10 & 4,3 \\
\hline Vücut ağırlığından memnuniyet durumu (n=230) & & \\
\hline Hiç memnun değilim & 34 & 14,8 \\
Memnun değilim & 44 & 19,1 \\
Fena değil & 68 & 29,6 \\
Memnnum & 63 & 27,4 \\
Çok memnunum & 21 & 9,1 \\
\hline
\end{tabular}

Katılımcıların kendi beslenme tarzlarını değerlendirmelerinin istendiği soruya verdikleri yanıtlara göre, \%39,6's1 "ara sira yeterli beslendiğini", \%27,8'i "genellikle yeterli ve dengeli beslendiğini" \%19,1'i "yeterli ve dengeli beslenmediğini”, \%12,2'si "dikkat etmediğini", \%1,3'ü de "farkında olmadığını" belirtmiştir. Araştırma katılımcılarının $\% 73,5$ 'i dershanede bulundukları süre içerisinde beslenme alışkanlıklarının değiştiğini düşünmektedir.

Son bir hafta içinde kalınan yer dışında yenilen toplam öğün sayısının bazı değişkenlerle yapılan korelasyon analizine göre dışarıda yenilen toplam öğün sayısı ile katılımcıların yaşları $(\mathrm{r}=-0,34, \mathrm{p}=0,001)$ ve aylık gelirleri $(\mathrm{r}=-0,17, \mathrm{p}=0,016)$ arasında istatistiksel açıdan anlamlı ve zayıf bir korelasyon olduğu saptanmıştır. Dışarıda yenilen toplam öğün sayısı ile VKİ arasında ise anlamlı bir korelasyon yoktur( $\mathrm{r}=-0,08, \mathrm{p}=0,19)$.

Beslenme durumundan memnuniyet üç başlıkta gruplanarak (beslenme durumundan memnun olmayanlar, beslenme durumunu fena bulmayanlar ve beslenme durumundan memnun olanlar) yapılan analizlerde yaş, öğrenim durumu ve VKİ anlamlı değişkenler olarak dikkati çekmektedir (Tablo 7).

Tıp fakültesi mezunu ya da öğrencisi olmanın beslenme memnuniyeti üzerine etkisiyle ilgili olarak vücut kitle indeksini göz önüne alarak bir değerlendirilme yapıldığında öğrencilerde fazla kilolu ve şişman olanların yüzdesi \%17,2 iken mezunlarda \%34,0 olarak tespit edilmiş ve aradaki fark istatistiksel olarak anlamlı bulunmuştur $(\mathrm{p}=0,009)$. Yaş gruplarına göre değerlendirme yapıldığında ise yaş grupları arasında VKİ açısından anlamlı bir farklılık olmadı̆̆ 
Tablo 7. Araştırma katılımcılarının beslenme durumundan memnuniyetlerinin bazı değişkenlerle ilişkisi.

\begin{tabular}{|c|c|c|c|c|c|}
\hline Özellikler & $\begin{array}{l}\text { Memnun değil } \\
\text { Sayı (\%) }\end{array}$ & $\begin{array}{c}\text { Fena bulmayan } \\
\text { Sayı }(\%)\end{array}$ & $\begin{array}{r}\text { Memnun } \\
\text { Sayı (\%) }\end{array}$ & Ki-kare & $\mathbf{p}$ \\
\hline \multicolumn{6}{|l|}{ Cinsiyet $(n=231)$} \\
\hline Erkek & $24(26,4)$ & $33(36,3)$ & $34(\% 37,3)$ & 3,04 & 0,21 \\
\hline Kadın & $52(37,1)$ & $46(32,9)$ & $42(30,0)$ & & \\
\hline \multicolumn{6}{|l|}{ Yaş $(n=231)$} \\
\hline 25 yaș altı & $51(28,7)$ & $67(37,6)$ & $60(33,7)$ & 7,09 & 0,029 \\
\hline 25 yaş ve üstü & $25(47,2)$ & $12(22,6)$ & $16(30,2)$ & & \\
\hline \multicolumn{6}{|l|}{ Yaşam yeri $(n=231)$} \\
\hline Aile yanı & $27(35,5)$ & $25(32,9)$ & $24(31,6)$ & 0,35 & 0,84 \\
\hline Diğer & $49(31,6)$ & $54(34,9)$ & $52(33,5)$ & & \\
\hline \multicolumn{6}{|c|}{ Öğrenim durumu $(n=231)$} \\
\hline Tıp fakültesi öğrencisi & $49(27,5)$ & $68(38,2)$ & $61(34,3)$ & 10,88 & 0,004 \\
\hline Tıp fakültesi mezunu & $27(50,9)$ & $11(20,8)$ & $15(28,3)$ & & \\
\hline \multicolumn{6}{|l|}{ VKİ $(n=227)$} \\
\hline Zayıf ve normal kilolu & $52(29,1)$ & $67(37,4)$ & $60(33,5)$ & 7,21 & 0,027 \\
\hline Fazla kilolu ve şişman & $23(47,9)$ & $10(20,8)$ & $15(31,3)$ & & \\
\hline
\end{tabular}

\section{Tartışma}

Araştırma, TUS dershanesine devam eden tıp fakültesi öğrencileri ve mezunlarında yapılmıştır. Ülkemizde yıllar içerisinde tıp fakültesi ve öğrenci sayılarındaki artış, uzmanlık eğitimi almak isteyenlerin sayısını da artırmış ve uzmanlık eğitimi almak isteyen adayların seçimi için 1987 yılında Tipta Uzmanlık Sınavı (TUS) uygulaması başlatılmıştır. Bu sınav "bilişsel bilgiyi çoktan seçmeli sorularla" ölçen bir sınavdır [11]. $\mathrm{Bu}$ sınavlara yönelik olarak son yıllarda sayıları giderek artan TUS hazırlık dershaneleri kurulmuştur. TUS, tıp öğrencilerinin eğitimini, sosyal hayatını, sağlığını ve özellikle klinik tutum ve davranışlarını etkilemektedir [12].

Araştırma grubu genç, kadın ve öğrenci ağırlıklıdır. Öğrenci ağırlıklı olmaları aylık gelir açısından ailelerinden aldıkları ve/veya burs vb olanakları ölçüsünde ekonomik desteğin ön planda olmasını getirmektedir. Bu ekonomik profilin, beslenme alışkanlıklarını etkilemesi beklenmektedir. Beslenme alışkanlığını etkileyen bir diğer durum da yaşanılan yer ve bu yerdeki beslenme düzenidir. Katılımcıların yaklaşı \%33'ü ailesinin yanında yaşamakta, yarıdan fazlası arkadaşlarıyla evde ve yurtta kalmaktadır. Barınılan yer ve bu yerdeki beslenme alışkanlıkları katılımcıların, barındıkları bu yer dışında yemek yeme sıklığını ve yedikleri besinlerin içeriğini etkileyen bir faktör olabilir.

Katılımcıların hesaplanan vücut kitle indeksleri doğrultusunda, yaklaşık olarak \%6'sının zayıf, \%73'ünün normal kilolu, \%18'inin kilolu, \%4'ünün şişman olduğu belirlenmiştir. Erciyes Üniversitesi'nde 2010 yılında benzer bir grupta yapılan bir çalışmada şişmanlık yüzdesi \%8,5 olarak belirlenmiştir, çalışma grubunda şişmanlık sıklığı bu çalışmaya göre daha düşük bulunmuştur [13]. Ayrıca 2004 yılında yurtdışında yapılan bir araştırmada da şişmanlık yaklaşık \%8,4-8,9 düzeyindedir [14]. Bu farklılığı oluşturabilecek birçok faktörden söz edilebilir. Bunlar arasında çalışma grupları ve araştırma yöntemlerinin farklı1ığı, ek olarak göz önüne alınamayan başka etkenler de yer alabilir.

Son bir hafta içinde dişarıda yenilen öğünler arasında öğlen öğünleri $(\% 90,4)$ önde gelmektedir. Katılımcıların ağırlıklı olarak öğrenci olmaları, zorunlu olarak hafta içi günlerde öğle yemeğinin okulda yenmesini gerektiren bir durum yaratmış olabilir. $\mathrm{Bu}$ durumu ortaya koyacak bir veri araştırmada elde edilmemiştir ancak okulda tercih edilen öğünlerin içeriğinin değerlendirmede önemli olacağını düşündürmektedir. Ankara'da veterinerlik fakültesi öğrencilerinde yapılan bir araştırmada araştırma kapsamındaki öğrencilerin \%39'unun haftada 3-5 kez, \%24'ünün her gün "lokanta-restaurant-fastfood tarzı yerlerde yemek yediği" belirlenmiştir. Bu bulgu barınma yerlerine göre analiz 
edildiğinde evde ailesinden ayrı yaşayan öğrencilerin \%24'ünün, yurtta kalan öğrencilerin de \%41'inin her gün dışarıda yemek yeme alışkanlığına sahip olduğu tespit edilmiştir [15].

Araştırmada kahvaltıyı dışarıda yapmayı tercih edenlerin yüzdesinin $(\% 58,5)$ diğer öğünlere göre düşüklüğünün "öğün atlama” ile ilişkili olabileceği söylenebilir. Bu durumu destekleyen bir bulgu Atatürk Üniversitesi’nde lisans öğrencileri üstünde yapılan bir araştırmada elde edilmiştir. Adı geçen araştırmada kahvaltı diğer öğünlere göre daha fazla atlanan bir öğün olarak (yaklaşık \%40) tespit edilmiştir [16]. Üniversite öğrencilerinde yapılan bir başka çalışmada ise en çok atlanan ögün \%65,8 ile öğle yemeği olarak dikkat çekmektedir[8]. Ege Üniversitesi öğrencilerinden oluşan bir grupta yapılan bir çalışmada da kahvaltı $(\% 44,0)$ ve öğle yemeği $(\% 41,0)$ en çok atlanan ögünler olarak saptanmıştır. Bu araştırmada öğünlerini düzenli olarak yiyen öğrencilerin sabah ve öğle öğünlerinde ağırlıklı olarak hazır yemekleri tercih ettikleri belirlenmiş̦tir(Sırasıyla \% 77,6 ve \%69,6) [17]. Isparta'da yapılan bir başka çalışmada da sabah öğünü atlayan öğrenci oranı \%27, öğlen ögününü atlayan öğrenci oranı da \%24 olarak belirlenmiştir [18]. Görüldügü gibi dışarıda yenilen yemekler ve atlanan ögünler ile ilgili olarak daha çok üniversite öğrencilerinde yapılan çalışmalara rastlanmaktadır. Buna karşın çalışma kapsamında araştırmanın gerçekleştirildiği TUS dershanesine devam eden tıp fakültesi mezunları da yer almaktadır. Bu durum karşılaştırılabilirliği etkileyen bir faktör olabilir.

Katılımcıların dörtte üçe yakını dershaneye devam ettikleri günlerde dışarıda yemek yediklerini belirtmişlerdir. Katılımcıların dershaneye gittikleri günlerde günlük yemek için ayırdıkları para miktarlarına bakıldığında ise yarıdan fazlasının $(\% 52,2)$ günlük 10 TL ve altında beslenme için para ayırdığı görülmektedir. Gaziantep Üniversitesi'nde yapılan bir araştırmada benzer grupta yer alan "lisans ve lisansüstü" öğrencilerinin aylık yemek için ayırdıkları para miktarları ise büyük çoğunlukta 150-450 TL şeklinde bulunmuştur ve bu tutar günlük olarak 5-15 TL civarında bir tutara karş11ık gelmektedir [19]. Bu tutarlar dışarıda yenen yemeklerde ucuzluk faktörünün önemli olabileceği düşündürse de araştırmada bunu ayırt edecek bir veriye ulaşılamamıştır.

Dershaneye gidilen günlerde tüketilen yiyecek türleri arasında "ayaküstü beslenme" tarzında yiyeceklerin ön planda olduğu görülmektedir. Bu kapsamda ekmek arası ürünler, lahmacun/pide/pizza ve hamburger en çok tercih edilen üç yiyecek türüdür. Diğer yandan balık, makarna, kuru baklagil ve sebze yemekleri tercih edilmemektedir. Araştırmada bu ögün tercihlerinin nedenlerine yönelik olarak bir irdeleme yapılmamıştır ancak araştırma katılımcılarının dershaneye devamları sırasında dışarıda yedikleri yiyecekleri seçimlerinde belirleyici 3 faktörü belirtmelerine dair soruya verdikleri yanıtlar incelendiğinde katılımcılardan "çabuk yenme, lezzet ve temizlik" özelliklerini bir arada değerlendirdikleri dikkati çekmektedir. Balıkesir Üniversitesi'nde yapılan bir araştırmada yemek seçiminde etkili faktörler "temizlik" ve "doyuruculuk" seçeneklerinde yoğunlaşmıştır [8]. Yemeklerin temiz olmasının iki çalışmada da öne çıktığı görülmektedir.

Dershanede bulunulan günlerde yenilen yiyeceklerin sağlıklı bulunup bulunmadığı ile ilgili görüşler incelendiğinde yaklaşık beşte üçünün ürünleri "sağliksız" bulduğunu belirtmiştir. Bu sonuç eğitim kurumlarında sağlıklı ve dengeli beslenme olanaklarının ileri yaş gruplarında da üzerinde durulması gereken bir konu olduğunu düşündürmektedir. Balıkesir Üniversitesi'nde yapılan araştırmada ise sağlıklı beslendiğini düşünen katılımcılar \%21,1'de kalırken, sağlıklı beslenmediğini belirtenlerin yüzdesi \%78,9 çıkmıştır [8]. Diğer yandan kaldıkları yer dışında yemek tercihleri konusunda ailelerinin düşüncelerine ilişkin olarak, yaklaşık ailelerinin üçte birinin katılımcıların yediklerini bildikleri ve uygun bulmadıklarının belirlenmesi geliştirilecek müdahale programları açısından göz önüne alınması gereken bir sonuçtur. Buradan hareketle, TUS dershanesine devam edenlerin benzer gruplara göre "daha sağlıklı ve dengeli beslendiklerini düşündükleri” söylenebilir. Buna karş1lık katılımcıların üçte biri kendi beslenme tarzlarından memnun değillerdir. Bu memnuniyetsizlik, fizik aktivite durumunda yarıdan 
fazlaya çıkmakta, vücut kitle indeksinden memnun olmamada ise \%34 civarında kalmaktadır. Bu manzara tıp fakültesi öğrenci ve mezunlarının sağlıklı yaşam davranışları açısından kendi durumlarından genel olarak memnun olmadıklarını düşündürmektedir. Aldıkları mesleki eğitimin bu konuda etkisi olması muhtemeldir. Erzurum'da üniversite öğrencilerinde yapılan bir çalışmada öğrencilerin \%77'sinin spor yapmadığ belirlenmiştir [16]. Dokuz Eylül Tıp Fakültesi birinci sınıf öğrencilerinde yapılan bir çalışmada ise spor yapmayanlar \%75,4 sıklığında bulunmuştur [20]. Afyon ve Denizli'de Üniversite ve devlet hastanelerinde görev yapan sağlık çalışanlarının, sağlıklı yaşam davranışı biçimlerini belirlemek amacıyla yapılan bir başka çalışmada da araştırmaya katılan sağlık çalışanlarının \%58,9'unun hiç egzersiz yapmadığı saptanmıştır [21].

Tıp fakültesi öğrencilerinin ve mezunlarının düzenli fizik egzersiz yapmıyor olmaları gerek kendi sağlıkları açısından gerekse de hizmet verdikleri topluma örnek oluşturan bireyler olmaları açısından üzerinde durulması gereken bir konudur. Hekimler ve sağlık çalışanları, "mesleki sorumlulukları ve sosyal rolleri" ile rol modeli olma özelliğine sahiptirler ve bu nedenle sağlıklı yaşam davranışlarına ve biçimlerine sahip olmaları önemlidir [21].

Diğer yandan katılımcıların yaklaşık beşte biri yeterli ve dengeli beslenmediğini belirtmiştir. Dörtte üçe yakını ise dershaneye devam etmenin beslenme alışkanlıklarını değiştirdiğini düşünmektedir. TUS tıp fakültesi öğrenci ve mezunları için önemli bir sınavdır. Araştırmada beslenme alışkanlıklarını değişim nedenleri sorgulanmamıştır ancak beslenme alışkanlığında değişikliğin ortaya çıkması, dershaneye devam sırasında tüketilecek gıdaların sağlıklı olup olmamasının önemli olduğunu göstermektedir. $\mathrm{Bu}$ anlamda dershane kantini başta olmak üzere gıda ve yemek satış yerlerindeki gıda ve yemek türlerinin sağlıklı içerikte olması bireyin yeterli ve dengeli beslenme alışkanlıklarına katkıda bulunacaktır.

Hekimlik mesleğine başlamak üzere olan son sınıf öğrencilerinde yapılan bir araştırmada öğrencilerin \%34'ü "en çok motivasyonlarını arttırdığı” için TUS dershanesine gittiğini, yaklaşık yarısı da beslenme durumunun etkilendiğini belirtmiştir [22]. TUS, uzun ve zor bir eğitim olan tıp eğitiminin öğrenciler üzerindeki etkilerine ek bir faktör olarak etki eden ve öğrenci ve mezunların beslenme alışkanlıklarını değiştiren bir süreç olarak gözükmektedir.

Araştırmada, son bir hafta içinde kalınan yer dışında yenilen toplam ögün sayısı, yaş ve aylık gelir ile negatif yönde anlamlı ancak zayıf bir korelasyon göstermektedir. VKİ ile ise bu anlamlılık saptanmamıştır. Yaş ve gelir arttıkça dışarıda yenilen öğün sayısı azalmaktadır ancak aradaki ilişki zayıftır. Bu bulgu mezunların da araştırma grubunda yer almasından kaynaklanmış olabilir. Ekonomik olanaklar beslenme alışkanlıklarını etkilemektedir. Yetersiz ekonomik olanaklar beslenmeden çok "karın doyurma" amaçlı yemek yeme alışkanlığını getirmektedir [23]

Beslenme durumundan memnuniyetle yaş, öğrenim durumu ve VKİ ilişkili bulunmuştur, cinsiyet ve aile yanında olma durumu ile ilgili ise anlamlı bir farklılık yoktur. Ege Üniversitesi öğrencilerinde yapılan bir çalışmada barınma yerinin öğrencilerin hazır yemek tercihlerinde anlamlı bir farklılı̆̆ yaratmadığı belirlenmiştir. Buna karşın lokanta ve ev yemeklerinde aile ya da arkadaşlarıyla ve de barınanların ev yemeklerini, yurtta barınan öğrencilerin ise lokanta yemeklerini anlamlı düzeyde daha fazla oranda tercih ettikleri belirlenmiştir [17]. Benzeri bir durum bu çalışmada da gerçekleşmiş olabilir ancak katılımcıların yemek tercihleri farklı sorgulandığı ve daha çok yedikleri ürün tercihleri saptanmaya çalışıldığ için karşılaştırma yapma olanağ yoktur.

Araştırma sonuçlarına göre beslenme durumundan memnun olmayanlar daha fazla oranda 25 yaş üstü, mezun ve fazla kilolu ya da şişmandır. Mezunlarda fazla kilolu ya da şişman olanların yüzdesi öğrencilere göre anlamlı düzeyde yüksektir ancak yaş gruplarında ise VKİye göre anlamlılık yoktur. Bu bulgu, öğrenci ya da mezun olmaktan çok vücut kitle indeksinin memnuniyette belirleyici olduğunu düşündürmektedir. Benzer bir durum yaş 
grupları için ise söz konusu değildir. Bu durum, mezunlar ve öğrenciler arasındaki farklılığı VKİ ile ilişkili olabileceğini ancak aynı durumun yaşa göre analiz yapıldığında söz konusu olmadığını, mezunların öğrencilere göre daha fazla düzeyde fazla kilolu ya da şişman olmalarının beslenme memnuniyetsizliğini etkileyen temel faktör olabileceğini göstermektedir. VKİnin mezunlarda daha fazla memnunluk üzerine etki etmesinin birçok nedeni olabilir. Okulun bitmesi ile değişen beslenme, fizik aktivite vb alışkanlıklar etkili olabilir. Çalışma grubunun beşte birini mezunlar oluşturmasına karşın araştırma katılımcılarının \%7,4'ü gelir getirici bir işte çalışmaktadır. Bu durum mezun olduktan sonra herhangi bir yerde çalışmadan TUS'a hazırlanma amacıyla mezunların dershaneye devam ettiklerini göstermektedir, bu da beslenme ile ilgili alışkanlıkları etkileyen bir faktör olabilir.

Sonuç olarak bu araştırmada Ankara'da bir TUS dershanesine devam eden tıp fakültesi öğrencisi ve mezunlarının dershaneye devamlarının büyük oranda beslenme alışkanlıklarını değiştirdiği, dışarıda daha çok "ayaküstü” yiyeceklerin tercih edildiği, başta fizik aktivite durumu olmak üzere, beslenmeleri ve vücut ağrilıklarından memnuniyetsizliklerinin kayda değer olduğu ve beslenme memnuniyetsizliğini etkileyen faktörler arasında VKI'lerinin ön planda olduğu belirlenmiştir. Gerek tıp eğitiminde sağlıksız yaşam davranışlarının olumsuz sonuçlarına dair mesleki eğitim alan gerekse de topluma davranışlarıyla model oluşturacak olan hekimlerin sağlıklı yaşam davranışları geliştirmeleri ve bu amaçla yapılacak çalışmalar sağlığın geliştirilmesi alanına katkı sağlayacaktır.

\section{Kaynaklar}

1. Tanır F, Şaşmaz T, Beyhan Y, Bilici S. Doğankent Beldesinde Bir Tekstil Fabrikasında Çalışanların Beslenme Durumu. Mesleki Sağlık ve Güvenlik Dergisi 2001; 22-5.

2. Çalıştır B, Dereli F, Eksen M, Aktaş S. Muğla Üniversitesi Öğrencilerinin Beslenme Konusunda Bilgi Düzeylerinin Belirlenmesi. Uluslar arası İnsan Bilimleri Dergisi 2005; 2:1-8.

3. Aslan D, Gürtan E, Hacım A, Karaca N, Şenol E, Yıldırım E. Ankara'da Eryaman Sağlık Ocağı Bölgesi'nde Bir Lisenin İkinci Sınıfında Okuyan Kız Öğrencilerin Beslenme Durumlarının ve Bazı Antropometrik Ölçümlerinin Değerlendirmeleri. C. Ü. Tıp Fakültesi Dergisi 2003; 2: 55-62.

4. Önder FO, Kurdoğlu M, Oğuz G, Özben B, Atilla S, Oral SN. Gülveren Lisesi Son Sınıf Öğrencilerinin Bazı Beslenme Alışkanlıklarının Saptanması ve Bunun Malnütrisyon Prevalansı ile Olan İlişkisi. Hacettepe Toplum Hekimliği Bülteni 2000; 21: http://www.thb.hacettepe.edu.tr/arsiv/2000/sayi_1/baslik1.pdf (Erişim tarihi: 09.12.2013).

5. Toplumun Beslenmede Bilinçlendirilmesi, Saha Personeli İçin Toplum Beslenmesi Programı Eğitim Materyali. T.C. Sağlık Bakanlığı Temel Sağlık Hizmetleri Genel Müdürlüğü \& Hacettepe Üniversitesi Beslenme ve Diyetetik Bölümü. Haziran 2002. http://www.beslenme.gov.tr/content/files/yayinlar/kitaplar/diger_kitaplar/toplumu n_beslenmede.pdf (Erişim tarihi: 09.12.2013).

6. Pekcan G. Beslenme Durumunu Saptanmas1. Sağlık Bakanlığı Yayın No: 726. Birinci Basim 2008 Şubat. Available at: http://www.beslenme.gov.tr/content/files/yayinlar/kitaplar/beslenme_bilgi_serisi_ 1/a14.pdf (Erişim tarihi: 09.12.2013).

7. Pekcan H. Adelosan (Delikanlı) sağlığı. Içinde: Güler Ç. Akın L.(Ed.). Halk Sağlığı Temel Bilgiler, Cilt III. Hacettepe Üniversitesi Yayınları, Ankara, 2012: pp: 486-538.

8. Yılmaz E, Özkan S. Üniversite Öğrencilerinin Beslenme Alışkanlıklarının İncelenmesi. Frrat Sağlık Hizmetleri Dergisi 2007; 6: 87-104. 
9. Özdoğan Y, Yardımcı H, Özçelik AÖ. Yurtta kalan üniversite öğrencilerinin beslenme alışkanlıkları. Karadeniz Sosyal Bilimler Dergisi 2012; 15: 139-49.

10. Milli Eğitim Bakanlığı Aile ve tüketici hizmetleri, gençlerde temel ihtiyaçlar. MEB eğitim modülleri, 2011. Available at: http://megep.meb.gov.tr/mte_program_modul/moduller_pdf/Gen\%C3\%A7lerde\%20Tem el\%20\%C4\%B0htiya\%C3\%A7lar.pdf (Erişim tarihi: 09.12.2013).

11. Çicek C, Terzi C. Tıpta Uzmanlık Eğitimi, İzmir Ölçekli İki Araştırma ve Karşılaştırmalı Sonuçları. Türk Tabipleri Birliği Yayını, Ankara 2006.

12. Özyıldırım E, Alkan M, Bilge E, Koşan Z, Ezmeci T. Tıpta Uzmanlık Sınavının Dönem 6 Öğrencilerinin Sosyal Yaşamına, Sağlığına, Klinik Tutum ve Davranışlarına Etkisi; 15.Ulusal Halk Sağlığı Kongresi. Kongre kitabı, bildiri no: 543; 2012; 6p: 691-3. http://halksagligiokulu.org/anasayfa/?task=view\&id=278\&catid=57 (Erişim: 09.12.2013)

13. Soyuer F, Ünalan D, Elmalı F. Normal ağırlıklı ve obez üniversite öğrencilerinde fiziksel aktivite. Uluslararası İnsan Bilimleri Dergisi 2010; 2: 862-72.

14. Gordon-Larsen P, Adair LS, Nelson MC, Popkin BM. Five-year obesity incidence in the transition period between adolescence and adulthood: the National Longitudinal Study of Adolescent Health. Am J Clin Nutr 2004; 80: 569-75.

15. Cevger Y, Aral Y, Demir P, Sarı̈zkan S. Ankara Üniversitesi Veteriner Fakültesi intern öğrencilerinde hayvansal ürünlerin tüketim durumu ve tüketici tercihleri. Ankara Üniversitesi Vet Fak Derg 2008; 55: 189-94.

16. Vançelik S, Önal SG, Güraksın A, Beyhun E. Üniversite Öğrencilerinin Beslenme Bilgi ve Alışkanlıkları ile İlişkili Faktörler. TAF Prev Med Bull 2007; 6: 242-8.

17. Oluk EA, Oluk S, Davaslığlu EN. Ege Üniversitesi Öğrencilerinin Öğün Düzenleri Ve Yemeklik Baklagil Tüketim Durumları. C.B.Ü. Fen Bilimleri Dergisi 2011; 7.2: 41- 50.

18. Orak S, Akgün S, Orhan H. Süleyman Demirel Üniversitesi öğrencilerinin beslenme alışkanlıklarının araştırılması S.D.Ü. Tıp Fak. Derg 2006; 2: 5-11.

19. Olcay A, Akın A, Şimşek MY. Beslenme Anlayışının Diyet-Vücut Ağırlığı Kontrolü Tutum Ve Davranışlarına Yansımasında Eğitim Düzeyinin Belirleyiciliği. Alatoo Academic Studies 2011; 2: 270-86.

20. Bayrak U, Gram E, Mengeş E, Okumuş ZG, Sayar HC, Skrijelj E, Açıkgöz A, Çehreli R, Ellidokuz H. Üniversite Öğrencilerinin Sağlıkla İlgili Alışkanlıklar ve Kanser Konusundaki Bilgi ve Tutumları. Dokuz Eylül Üniversitesi Tıp Fakültesi Dergisi 2010; 3: 95-104.

21. Yalçınkaya M, Özer FG, Karamanoğlu AY. Sağlık Çalışanlarında Sağlıklı Yaşam Biçimi Davranışlarının Değerlendirilmesi. TAF Prev Med Bull 2007; 6: 409-20.

22. Yıldız AN, Kurt M, Öktem MŞ, Özcan S, Özdemir N, Temel F. Hacettepe Üniversitesi Tıp Fakültesi dönem VI öğrencilerinin tıpta uzmanlık sınavı (TUS) hakkındaki görüşleri. Hacettepe Tıp Dergisi 2008; 39: 60-7.

23. Korkmaz NH. Uludağ Üniversitesi Öğrencilerinin Spor Yapma ve Beslenme Alışkanlıklarının İncelenmesi. Uludağ Üniversitesi Eğitim Fakültesi Dergisi 2010; 2 : 399-413. 